\title{
The Impact of Social Media Marketing on Consumer Purchase Intention: Consumer Survey in Saudi Arabia
}

\author{
Esraa Alfeel \\ MBA Student, College of Business and Economics, Qassim University, Saudi Arabia \\ Dr. Zaid Ahmad Ansari \\ Associate Professor of Marketing, College of Business and Economics, Qassim University, Saudi Arabia
}

\begin{abstract}
The main purpose of the current research was to find out the impact of social media marketing on the purchase intention of the customers. The study was conducted in Saudi Arabia. It is a quantitative research based primary data collected through structured close ended questionnaire, distributed online. Results were drawn based on 121 responses using factor analysis, ANOVA and regression analysis. The results showed that $92.4 \%$ of the customer purchase intention has been explained by Social Media Marketing. The results are statistically significant.
\end{abstract}

Keywords: Social Media Marketing, Saudi Arabia, nnConsumer Purchase Intention

DOI: $10.7176 / \mathrm{JMCR} / 56-03$

Publication date:May $31^{\text {st }} 2019$

\section{Introduction}

Marketing is what an organization must do to create and exchange value with customers, this value creation is by meeting customer's need and marketing strategy which is the plan of sustained basis to create (Silk, 2006). Successful business depends on successful marketing, simply without marketing the company cannot create or exchange value with customers. One form of the marketing is E-marketing (electronic marketing) or digital marketing, which focuses on using information technology for the marketing activity. E-marketing increases efficiency and effectiveness in traditional marketing function, and the technology transforms many marketing strategies which results in new business models that add customer value and/or increase customer profitability (Strauss \& Forst, 2012). Social media is one big important facet of digital marketing that company must consider to marketing in and with nowadays. Social media is a term used to describe the type of media that is based on conversion and interaction between people online. People nowadays are multi-taskers and spend many of their waking hours tuning in to multiple media platforms at the same time, someone probably very comfortable surfing the web, texting their friends and perhaps talking on the phone while they sip a latte at the local coffee shop, these people recently called - digital natives. Today marketers have a huge set of new tools to reach those digital natives. In fact, for most companies now the question is not whether to include social media as a part of the communication mix, but how much to use (Tuten \& Michael, 2015).

Social media marketing has become a very critical subject to analyze. A study by DEI Worldwide (2008) prepared the following statistics: $70 \%$ of consumers visited social media platforms to get information, $49 \%$ of these consumers made a purchase decision depending on the information they got from the social media platforms, $60 \%$ said they may use social media sites to pass along information to others online, and $45 \%$ of those who searched for information through social media platforms participated in word-of-mouth. The report concludes that companies that do not activate social media in their online marketing strategy were missing an opportunity to reach consumers. Because the word of mouth and the information passing between customers through social media platforms, the value of one customer is worth far more than what he originally spends. So companies must think about the value of customers and also the influence of social media on them (Kim, 2012). What makes this type of marketing different is that the content is not generated as corporate monologue, such as in a newspaper or most company's websites, but as a conversation, with all participants having the ability to upload content and discuss, edit, or rate each other's content and sometimes these relationships based on these interactions being continued offline (Strauss and Forst,2012). This research investigated how can companies use social media marketing to influence consumer behavior specially their intention to purchase.

\section{Statement of Problem}

Today, everything is about Social Media. Some industry scholars claim that," if you do not participate in Facebook, YouTube, and Second Life, you are not part of cyberspace anymore "(Kaplan \&Heinlein,2010). The concept of Social Media must be in the top of agenda for businesses, decision makers and the most important for marketers. Social media interaction has become now a day an important part of almost each individual's everyday life. Platforms such as Facebook, Twitter, Instagram or LinkedIn have a large number of the users and they continue growing every second of the day. It is estimated that over 3.196 billion people are using social media in 2018 (Kemp, 2018). 
Social Media with all types enables organizations to engage in direct and adequate end-consumer contact with lower cost and with higher efficiency than traditional communication tools (Kaplan \& Heinlein, 2010). Our concentration in this paper is on using Social Media platforms in marketing and how will this affect consumer purchase intention. These growing numbers of social media users must attract marketers. Companies marketers must have recognized social media marketing as an important tool that must be a main part of their marketing strategies.

\section{Objective of the Study}

The objective of the study was to investigate the influence of social media marketing on the consumer purchase intention.

\section{Research Question}

How marketers can use social media to influence consumer purchase intention?

\section{Scope of the Study}

This research analyzes the impact of social media marketing on consumer purchase intention. Therefore, the research may be expanded to investigate the other stages of consumer behaviors related to purchase intention such as making decision or buying behavior.

\section{Relevance of the Study}

Social Media is a great factor that influences humans' life nowadays. The number of users of social media platforms increasing every single moment, according to (Kemp, 2018) there were more than 3.196 billion active social media platforms users world-wide. This growing number lures marketers to use social media platforms to help them to communicate better with consumers and determine their needs. This study aimed to find out the influence of social media marketing on consumers.

\section{Literature Review}

Various studies have been conducted on the social media marketing and its effect on consumer behavior specially the purchase intention. The study by Darbanand Li (2012) examined the impact of online social networks on consumers purchasing decision process in food retailer shops in Sweden. The researchers found that online social networks impact every step of consumer's purchasing decision process to different extent regarding food retailer shops. They also found that convenience was the main reason for this behaviour. Because of these convenience consumers spend more time on it. However, these features allow customers to interacts with supermarkets and other customers and reach to comments on supermarkets Facebook's page. The study by Gros (2012) aimed to explain the influence of social media on consumers' purchasing decision making process and if the influence has different levels at the various stages of this process. The study concluded that the influence of social media has different levels according to the stages the consumers go through during the purchasing decision making process. Depending on the stages of the process of decision making, the consumers showed to be more or less influenced by social media.

Research by Sema (2013) examined the influence of social media on travelers' decision-making for their future vacations. Study implemented in United States and the data collected using online research firm's domestic leisure travel panel and the condition of required respondents was they must have taken at least one trip in past year for vacation, enjoyment, or personal purpose at U.S. About 1,048 respondents filled the questionnaire. The sample depicted for this research balanced by race, gender, age, and ethnicity. The research found that the use of social media in travel planning influenced travel experience positively. It also approved that sharing behavior and the experience with social media positively related to travel-experience sharing on social media. These results showed that with increased perceived pleasure related positively with the use of social media as a source of planning to travel. Also there is a positive relationship between the level of experience with social media and sharing travel experiences on social media. Study conducted by Sano (2014) applied in Japan, aimed to explain how marketing activities in social media work in tourism industry, and how can travel agencies use social media marketing to increase customer satisfaction and make positive word-of-mouth as well as influence purchase intentions. The result showed that customer satisfaction influenced by social media behavior intention stronger than positive word of mouth.

Ahmed and Zahid (2014) aimed to examine the impact of social media marketing on brand equity and customer relationship management in terms of purchase intention. Findings of this study indicated that most significant factor which influenced purchase intention was customer relationships management. It also concluded that social media marketing positively influenced customer relationships and brand equity. Results also showed that social media marketing does not directly affect the customer's purchase intentions, customer's purchase intention increased when clothes brands care about them, then customers engage emotionally with the brand, as 
well as customer's awareness about the brand, satisfaction and word-of-mouth enhance the customer's purchase intentions. Study carried out by Chandio et al. (2015) investigated the impact of social media marketing on customer purchase intention in Pakistani perspectives. The study showed that the customer tried to find out the information regarding the brand as much as possible with ease. It also revealed that the perceived quality doesn't has significant relation with the purchase intention in the context of the social media marketing whereas the information search has the positive significant relation with the purchase intention. Word of mouth showed a positive significant relation with purchase intention because this variable carried trust with itself. A local study by Medabesh (2015) investigated the impact of online advertising on the marketing of tourism services which was applied in Jazan city in Saudi Arabia. Research results revealed that electronic advertising positively affected buying behavior of tourist.

According to Schivinski and Dabrowsk (2016) brand equity and brand attitude are influenced positively by social media interaction. The results showed that brand equity and brand attitude have a positive influence on purchase intention. Another local study of Khatibi (2016) attempted to explain how the influence of social media is reflected on consumer purchase decision making process. The study found that the influence of social media has different levels when customer going through various stages of the consumers' purchasing decision making process. The results of the research approved that consumers in Saudi Arabia are actively using social media platforms as a tool when they engage in the purchase decision. However, consumers are considered to be unwilling to sharing their opinions and word-of-mouth to other customers through social media platforms . It further approved that Saudi consumer were affected by social media in their purchase decision. The research by Akhtar et al. (2016) showed that there is a positive relationship between social media marketing and consumer purchase intention. It approved that as the firms increase their spending on marketing on social media, the profitability of the firms also enhanced. Social media marketing assists the firms to gain competitive edge and enhance the profitability of companies.

Alhadid and Alhadeed (2017) aimed is to examine the impact of social media marketing on purchase intention of used cars in Jordan. Results showed that increasing number of consumers use social media, all kinds of industries had to invest in social media to gain new consumers and reinforce relations with current ones. It also showed that the business can improve social media marketing in a way to ensure success thought long term strategy rather than simply concentrating on widely known applications and social media. They suggested that corporations need a set of rules to efficiently handle numerous types of social media as instrument of strategic marketing.

Research done by Alkaya and Taskin (2017) provided a general view of the relationship between social media and customer equity and gave mobile operators a tool that enabling them to forecast the purchase intention of their customer in the future more accurately. The results also provide a guide to managing marketing activities on social media platform. The study by Zabadiet et. al., (2017) investigated the role of social media platforms and how they can influence the consumers' intention to purchase, and impact on user's trust in a social commerce environment. The results revealed that trust is the most dominant construct and has a statistically significant effect on behavioral intention to purchase on the internet, followed by perceived usefulness of website. Study by Zhung (2017) attempted to assess the impact of social media marketing, brand loyalty and electronic word of mouth toward purchase intention. It applied in Malaysia using quantitative method and applied deductive approach using questionnaires. The research results concluded that social media has positive effect on behavior. With social media interaction consumer intention to buy or repurchase the product in the future increased. It also approved that consumer purchase intention affected positively by brand loyalty, consumers were willing to spend their time and their money for banks that they were loyal for. The results also showed that when customer perceived the information in the social media as worthy and unbiased, they would acquire this information in their decisions. The research by Scarth (2017) examined how social media communication influenced purchase intention of motor vehicle brands in South Africa. The results concluded that the brands examined has very positive image in respondents' minds, respondents were also perceiving tested brands as brands with good reputation which draw positive features in consumers' minds. Results also suggested that a strong sense of brand attitude is present in South African Millennial consumers of high price items and this displayed strong positive relationship of brand attitude and brand equity influencing Millennial purchase intention. Study by Eekan and Evas (2017) found that the effect of electronic word of mouth in social media on purchase intention remains uncertain.

Study by Arceo et al., (2017) suggested an explanation on how social media platforms and various types of social media users through online convergence ultimately influenced purchase intention in the restaurant industry. Quantitative method used to study the influence of social media platforms used to advertise foodstuff. The study revealed that influence to visit or dine in a restaurant can be attributed to different factors such as online convergence, social media platforms, the frequency of use and types of social media user. It also showed that different social media users through online convergence can influence consumers to visit or dine-in in restaurants. Social media not only impacts consumers but also businesses who exploit its free-of-charge, faster and accessible advantages. Research carried out by Toor, et al., (2017) examined the impact of social network marketing on consumer purchase intention and how it is affected by the mediating role of consumer engagement. Results of this 
study indicated that social network marketing is significantly related to consumer purchase intention. It further demonstrated that consumer engagement acts as a partial mediator in how social network marketing impact on consumer purchase intention.

Study carried out by Flórez et al., (2017) tries to understand the factors that motivate the use of social networks in the purchase decision of young university students. Research results concluded with a proper approach to the factors that can affect university students who intend to use social networks to buy. It recommended for companies to look for strategies that combine information transparency and stimulation of word-of-mouth communication among users if they wish to promote their products through social platforms, generating a larger impact on the purchase decisions of clients. A study which focuses in one social network 'Instagram' by Al-Najjar (2017) investigated the creation of the performance of luxury through marketing work done on the social site Instagram and the respondents' role in this performance. This was done through using three exemplary brands - Burberry, Louis Vuitton and Gucci - that represent the luxury fashion sector. The results showed positive attitudes from followers towards the brands, this positive attitude showed from the positive sensual expressions in comments about the brand and its practicality. This indicated and confirmed findings that consumers perceived the brand to be beneficial and therefore emotional attachment towards the brands were shown. Hence, follower's role on Instagram sees to boost the luxury performance of these brands. Moreover, results showed that positive comments can be treated as positive electronic word of mouth and it is in return favorable for the brand's economic value. The positive responses and attitudes that followers expressed through comments enhanced the feel of luxury in Instagram as a whole. Having harmony between the brand's identity and the perceived image create a pleasant atmosphere for both the brand and customer. The literature in general showed positive relationship between social media marketing and customers purchase intention in various industries.

\section{Research Methodology \\ Data Collection Type}

This study relies on primary data. The data collection tool in this study is questionnaire, it included 14 closed ended questions.

\section{Type of the Study}

A quantitative approach applied in this study to test the hypotheses.

\section{The Model}

Dependent variable: Customer Purchase Intention (CPI)

Independent variable: Social Media Marketing (SMM)

The model: $\mathrm{CPI}=\mathbf{f}(\mathrm{SMM})$

\section{Social Media Marketing}

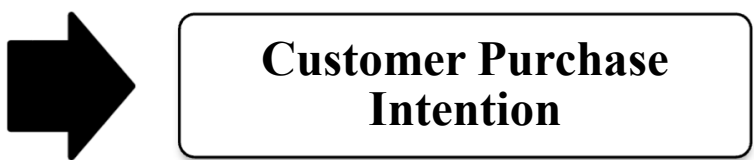

\section{Hypotheses}

H1o: There is no relationship between Social Media Marketing and Consumer Purchase Intention.

H1A: Social Media Marketing has a positive impact on Consumer Purchase Intention.

\section{Sampling Design}

The unit of analysis was individual who use social media networks selected randomly consisting 121 respondents. In order to ensure that the sample is appropriate one question about the average daily time spent on engagement in social media networks was asked.

\section{Statistical Analysis Techniques}

Using SPSS software, the researcher analyzed the data using :

- Frequencies, variance, mean, and standard deviation: for the purpose of descriptive data analysis.

- Correlation and regression: to analyze the impact of the social media marketing on the purchasing intention of the consumer.

- $\quad$ Testing the validity and reliability using factor analysis and Cronbach's alpha. 
Data analysis and interpretation

\section{Factor Analysis}

Table 1: Correlation Matrix

\begin{tabular}{|l|l|r|r|}
\hline \multirow{2}{*}{ Correlation } & Social Media Marketing & Social Media Marketing & Customer Purchase Intention \\
\cline { 2 - 4 } & Customer Purchase Intention & 1.000 & .520 \\
\hline \multirow{2}{*}{ Sig. (1-tailed) } & Social Media Marketing & .520 & 1.000 \\
\cline { 2 - 4 } & Customer Purchase Intention & & .000 \\
\hline
\end{tabular}

a. Determinant $=.729$

The main goal of correlation matrix is to check the pattern of the relationship; variables are reasonably well correlated. Table 1 showed that Pearson correlation between the independent variable and dependent variable is strong and positive in nature, that is reflected by the high value of 0.520 , which means increase in social media marketing is associated by increase in customer purchase intention and vice versa. There is no problem of Multicollinearity because the determinant is greater than 0.00001 .

Table 2; KMO Analysis

\begin{tabular}{|l|l|l|}
\hline Kaiser-Meyer-Olkin Measure of Sampling Adequacy & .796 \\
\hline \multirow{3}{*}{ Barlett's Test of Sphericity } & Approx. Chi-Square & 265.348 \\
\cline { 2 - 3 } & Df & 21 \\
\cline { 2 - 3 } & Sig. & .000 \\
\hline
\end{tabular}

KMO matrix measured the sampling adequacy, acceptable range value of KMO analysis is ' 0.5 and 0.7 ', the results in table 2, is 0.796 . Besides Bartlett's Test, showed statistically significant results and thus the data is appropriate for factor analysis. The significance of Bartlett's Test of Sphericity, which is below 0.05 and equals 0.000 , showed that the data that have been gathered is suitable and valid.

Table 3: Anti-image Matrices

\begin{tabular}{|c|c|c|c|}
\hline & & $\begin{array}{l}\text { Social Media } \\
\text { Marketing }\end{array}$ & $\begin{array}{l}\text { Customer Purchase } \\
\text { Intention }\end{array}$ \\
\hline \multirow{2}{*}{$\begin{array}{l}\text { Anti-image } \\
\text { Covariance }\end{array}$} & Social Media Marketing & .729 & $-.379-$ \\
\hline & $\begin{array}{l}\text { Customer Purchase } \\
\text { Intention }\end{array}$ & $-.379-$ & .729 \\
\hline \multirow{2}{*}{$\begin{array}{l}\text { Anti-image } \\
\text { Correlation }\end{array}$} & Social Media Marketing & $.500^{\mathrm{a}}$ & $-.520-$ \\
\hline & $\begin{array}{l}\text { Customer Purchase } \\
\text { Intention }\end{array}$ & $-.520-$ & $.500^{\mathrm{a}}$ \\
\hline
\end{tabular}

a. Measures of Sampling Adequacy(MSA)

Anti-image matrix is an important part of the output; the values of Sampling Adequacy (MSA) must be greater than 0.5 for independent variable. Table 3 points that the value of independent variable is well above 0.5 which is equal to 0.52 .

Communality is the proportion of common variance within a variable, Table 4 exhibits that $78.8 \%$ of variance associated with question $1,75.9 \%$ with question $2,48.4 \%$ with question 3 and so on.

\begin{tabular}{|c|c|c|}
\hline \multicolumn{3}{|c|}{ Table 4; Communalities } \\
\hline & Initial & Extraction \\
\hline Q1 & 1.000 & .758 \\
\hline Q2 & 1.000 & .759 \\
\hline Q3 & 1.000 & .484 \\
\hline Q4 & 1.000 & .572 \\
\hline Q5 & 1.000 & .424 \\
\hline Q6 & 1.000 & .747 \\
\hline Q7 & 1.000 & .695 \\
\hline
\end{tabular}




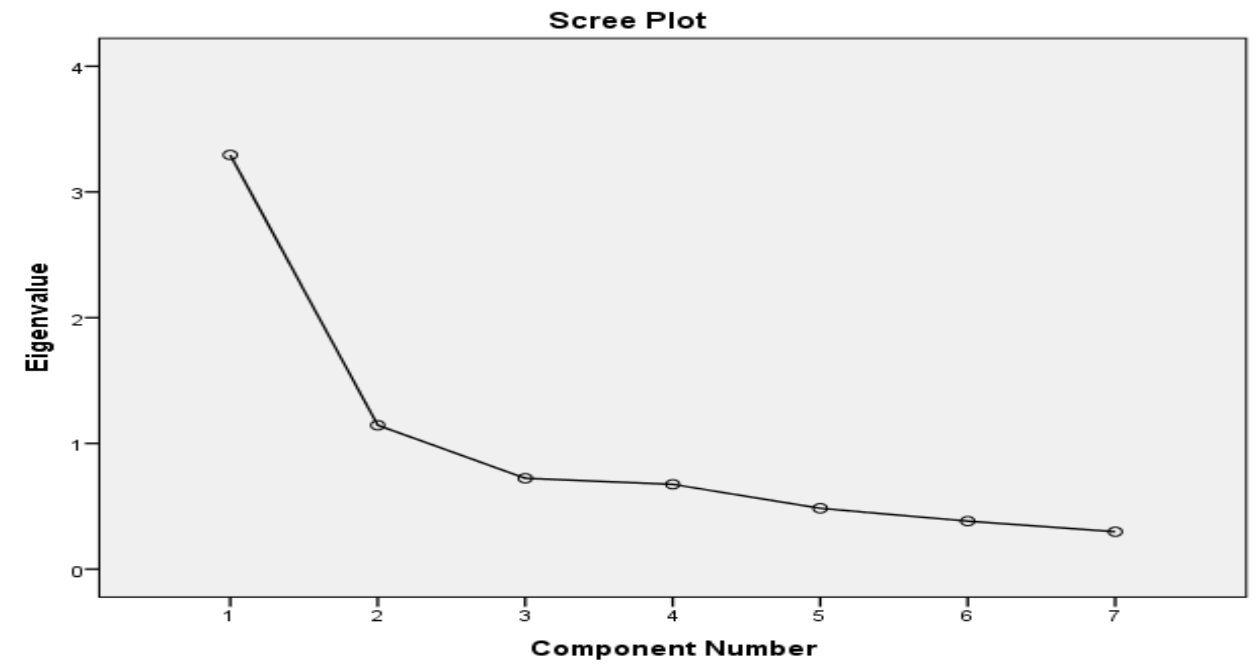

Figure 1

Table 5: Total Variance Explained

\begin{tabular}{|c|c|c|c|c|c|c|c|c|c|}
\hline \multirow{2}{*}{$\begin{array}{l}\text { Compone } \\
\mathrm{nt}\end{array}$} & \multicolumn{3}{|c|}{ Initial Eigenvalues } & \multicolumn{3}{|c|}{$\begin{array}{c}\text { Extraction Sums of Squared } \\
\text { Loadings }\end{array}$} & \multicolumn{3}{|c|}{$\begin{array}{l}\text { Rotation Sums of Squared } \\
\text { Loadings }\end{array}$} \\
\hline & $\begin{array}{c}\text { Tota } \\
1\end{array}$ & $\begin{array}{c}\% \text { of } \\
\text { Varian } \\
\text { ce }\end{array}$ & $\begin{array}{c}\text { Cumulative } \\
\%\end{array}$ & $\begin{array}{c}\text { Tota } \\
1\end{array}$ & $\begin{array}{c}\% \text { of } \\
\text { Varian } \\
\text { ce }\end{array}$ & $\begin{array}{c}\text { Cumulative } \\
\%\end{array}$ & $\begin{array}{c}\text { Tota } \\
1\end{array}$ & $\begin{array}{c}\text { \% of } \\
\text { Varian } \\
\text { ce }\end{array}$ & $\begin{array}{c}\text { Cumulative } \\
\%\end{array}$ \\
\hline 1 & $\begin{array}{r}3.29 \\
4\end{array}$ & 47.064 & 47.064 & $\begin{array}{r}3.29 \\
4\end{array}$ & 47.064 & 47.064 & $\begin{array}{r}2.60 \\
3\end{array}$ & 37.183 & 37.183 \\
\hline 2 & $\begin{array}{r}1.14 \\
4 \\
\end{array}$ & 16.347 & 63.412 & $\begin{array}{r}1.14 \\
4 \\
\end{array}$ & 16.347 & 63.412 & $\begin{array}{r}1.83 \\
6 \\
\end{array}$ & 26.229 & 63.412 \\
\hline 3 & .723 & 10.327 & 73.739 & & & & & & \\
\hline 4 & .675 & 9.639 & 83.378 & & & & & & \\
\hline 5 & .484 & 6.912 & 90.289 & & & & & & \\
\hline 6 & .382 & 5.457 & 95.746 & & & & & & \\
\hline 7 & .298 & 4.254 & 100.000 & & & & & & \\
\hline
\end{tabular}

Table 5, showed that the first six factors explain large amount of variance specially factor 1 , whereas subsequent factors explain only small amount of variance.

Table 6: Component Matrix

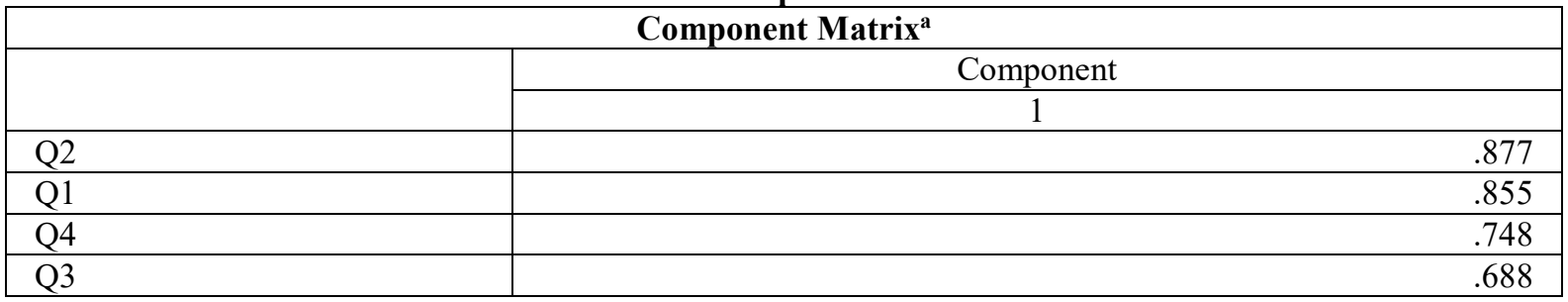

Extraction Method: Principal Component Analysis.

a. 1 components extracted.

Component matrix contains the loadings of each variable onto each factor extracted, demonstrated by Table 6 .

\section{Multiple Regression}

Table 7: Model Summary

\begin{tabular}{|l|c|c|c|c|c|}
\hline Model & $\mathrm{R}$ & R Square & $\begin{array}{c}\text { Adjusted R } \\
\text { Square }\end{array}$ & $\begin{array}{c}\text { Std. Error of the } \\
\text { Estimate }\end{array}$ & Durbin-Watson \\
\hline 1 & $.961^{\mathrm{a}}$ & .924 & .923 & .18278 & 1.991 \\
\hline
\end{tabular}

a. Predictors: (Constant), REGR factor score 2 for analysis 5, REGR factor score 1 for analysis 5

b. Dependent Variable: Customer Purchase Intention

Table 7, indicates that the multiple correlation coefficient $\mathrm{R}$ is equal 0.961 which points a good level of prediction of the dependent variable. $\mathrm{R}$ square is equal 0.924 , which means that $92.4 \%$ of the total variance in "customer purchase intention" has been explained by " social media marketing". 
The regression model well-fits the data due to that adjusted $\mathrm{R}$ square is less than $\mathrm{R}$ square with a very small difference, where it equals 0.037 . The Durbin-Watson is equal to 1.991 which is between the two critical values of $1.5<\mathrm{d}<2.5$. Therefore, we can assume that there is no first order linear auto-correlation in our multiple linear regression data.

Table 8: ANOVA ${ }^{\mathrm{a}}$

\begin{tabular}{|l|l|r|r|r|r|c|}
\hline \multicolumn{2}{|l|}{ Model } & Sum of Squares & \multicolumn{1}{c|}{ df } & Mean Square & F & Sig. \\
\hline \multirow{3}{*}{1} & Regression & 47.513 & 2 & 23.757 & 711.079 & $.000^{\mathrm{b}}$ \\
\cline { 2 - 7 } & Residual & 3.909 & 117 & .033 & & \\
\cline { 2 - 7 } & Total & 51.422 & 119 & & & \\
\hline
\end{tabular}

a. Dependent Variable: Customer Purchase Intention

b. Predictors: (Constant), REGR factor score 2 for analysis 5, REGR factor score 1 for analysis 5

ANOVA is analysis to tests the effect of Independent variables on dependent variables, large value of $F$ like what we have in the above value indicate that null hypothesis is wrong, so we reject the null hypothesis of equal population means and conclude that there is a (statistically) significant difference among the population means (Table 8).

Table 9: Coefficients ${ }^{\mathrm{a}}$

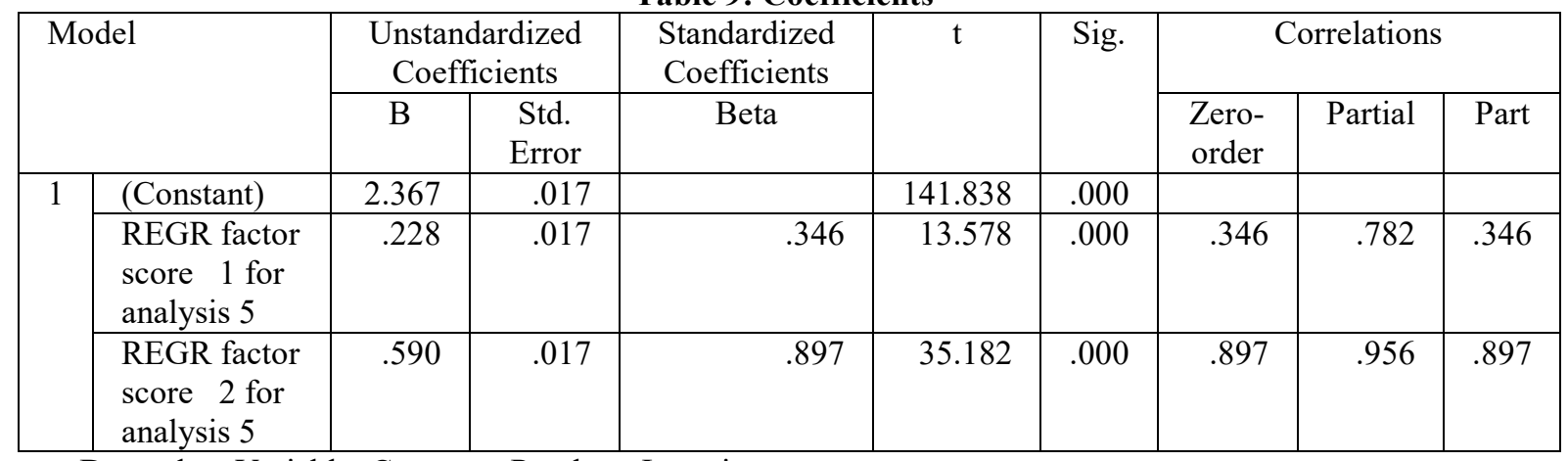

a. Dependent Variable: Customer Purchase Intention

In table 9, B column determine the expected change in dependent variable for each unit change in the associated independent, it is 0.409 here. The relative impact of independent variable on dependent variable is 0.520 . The information in the table above also allows us to check for Multicollinearity in our multiple linear regression model, VIF should be $<10$ for variables, VIF in the table above is equal to 1 so there is no problem of Multicollinearity.

Table 10: Residuals Statistics ${ }^{\mathrm{a}}$

\begin{tabular}{|l|r|r|r|r|r|}
\hline & \multicolumn{1}{|c|}{ Minimum } & \multicolumn{1}{c|}{ Maximum } & \multicolumn{1}{c|}{ Mean } & \multicolumn{1}{c|}{ Std. Deviation } & $\mathrm{N}$ \\
\hline Predicted Value & 1.0814 & 4.8746 & 2.3667 & .63188 & 120 \\
\hline Std. Predicted Value & $-2.034-$ & 3.969 & .000 & 1.000 & 120 \\
\hline Standard Error of Predicted Value & .017 & .075 & .027 & .011 & 120 \\
\hline Adjusted Predicted Value & 1.0851 & 4.8531 & 2.3673 & .63387 & 120 \\
\hline Residual & $-.52567-$ & .44885 & .00000 & .18124 & 120 \\
\hline Std. Residual & $-2.876-$ & 2.456 & .000 & .992 & 120 \\
\hline Stud. Residual & $-3.152-$ & 2.477 & $-.002-$ & 1.009 & 120 \\
\hline Deleted Residual & $-.63151-$ & .45653 & $-.00063-$ & .18801 & 120 \\
\hline Stud. Deleted Residual & $-3.281-$ & 2.533 & $-.001-$ & 1.019 & 120 \\
\hline Mahal. Distance & .003 & 18.952 & 1.983 & 3.047 & 120 \\
\hline Cook's Distance & .000 & .667 & .013 & .062 & 120 \\
\hline Centered Leverage Value & .000 & .159 & .017 & .026 & 120 \\
\hline
\end{tabular}

a. Dependent Variable: Customer Purchase Intention

Table 10 shows spread of values that the model predicts and the range of error within the model. 


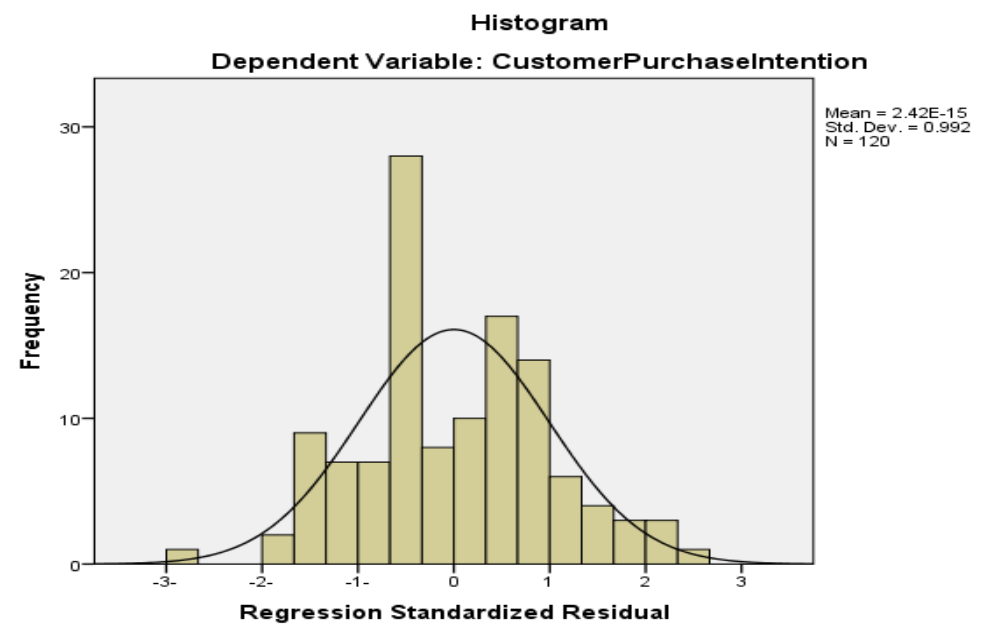

Fig. 1: Histogram showing dependent variable

Figure 2

Fig.1 examines the multivariate normality of the dependent variable using histogram, which denotes normal distribution of collected data.

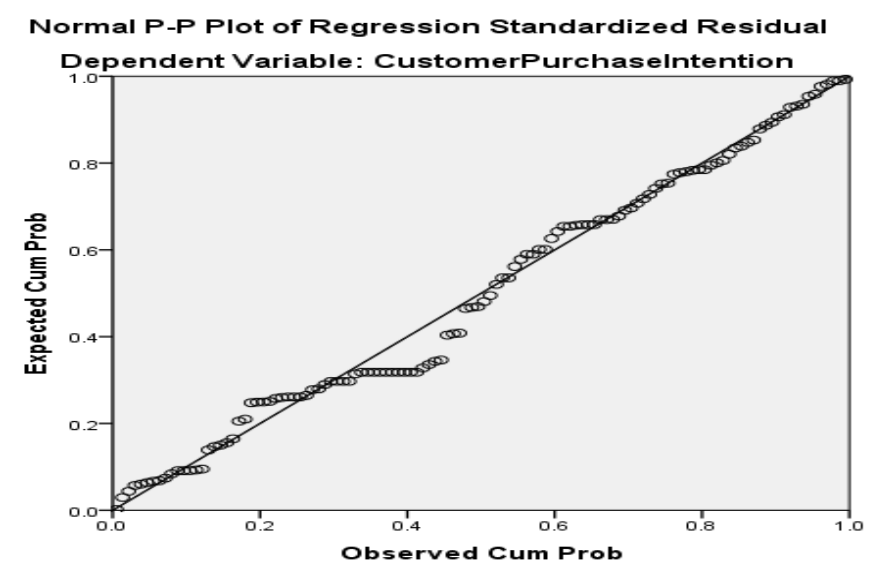

Figure 3: Normal P-P Plot

Also using P-P plot, we can check for normality of residuals. Fig. 2 shows that the points follow the normal line with no deviations. This indicates that the dependent variable is normally distributed.

Table 11: Reliability Statistics

\begin{tabular}{|c|c|}
\hline Cronbach's Alpha & N of Items \\
\hline .810 & 7 \\
\hline
\end{tabular}

Table 11 indicates that the Cronbach's Alpha coefficient is above 0.7 and equals 0.81 , suggesting that the items have relatively high internal consistency and the reliability of the scale is good and acceptable.

\section{Conclusion}

Present study investigated the impact of Social Media Marketing on Consumer Behaviour. A good number of researches have been done on the topic specially in developed countries. However presently the Social Media have gained tremendous popularity in developing countries including the Middle-East in general and Saudi Arabia in particular. The results of this research showed that Social Media Marketing influences the customer purchase intention positively, therefore based on the findings of this research Social Media Marketing cannot be avoided by the companies. Infact social media marketing should be appropriately planned and implemented to increase the sales and profit. The findings of this study is similar to the findings of previous studies namely Darban and Li (2012), Gros (2012). Importantly, Social Media Marketing influences different sectors such as travel and tourism, Sema (2013, Sano (2014), it also influences the brand equity and customer relationship management (Ahmed and 
Zahid (2014). Social Media Marketing has impact across different nations such as Pakistan Chandio et. al., (2015), Saudi Arabia Khatib (2016). Thus from the current research and the previous researches it can be concluded that the Social Media Marketing positively impacts consumer behaviour.

\section{References}

Ahmed, M., and Zahid, Z., (2014). Role of social media marketing to enhance CRM and brand equity in terms of purchase intention. Asian Journal of Management Research. 4(3), pp. 533-549.

Akhtar, N., Tahir, M., and Asghar, Z. (2016). Impact of social media marketing on consumer purchase intention. International Review of Social Sciences. 4(10), pp. 385-394.

Alhadid, A. and Alhadeed, A., (2017). The impact of social media marketing on purchase intention. International Business Management.11(11), pp.1844-1847.

Alkaya, A. and Taskin, E (2017). The impact of social media pages on consumer equity and purchase intention: an empirical study of mobile operators. Journal of Business Research Turk. 9(3), pp.122-133.

Al-Najjar, N., (2017). Luxury in Instagram's Eyes Burberry, Louis Vuitton \& Gucci. Published thesis (Master degree). Erasmus University Rotterdam.

Arceo, P., Buenaventura, M., Cumahig, I., Mesa, M. and Tenerife, J., (2017). The Impact of Social Media Platforms to Online Consumers' Intention to Purchase in Food Industry. In: Proceedings of the Sixteenth Asia-Pacific Conference on Global Business, 21- 22 December 2017. Taipei. Taiwan.

Chandio, Z., Ahmed, S., and Zafar, S., (2015). Impact of social media marketing on consumer purchase intention. IBT journal of business studies.11(11), p.119-129, [online] Available at $<$ http://ibt.edu.pk/ibt/jurnals/7_ibt.biztek > [ Accessed 19 September 2017].

Erkan, I. and Evans, C., (2016). The impact of electronic word of mouth in social media on consumers purchase intentions.

Flórez, L., Escobar, M., Restrepo, A., Botero, D. and Arias, A. (2017). Influence of social networks on the purchase decisions of university students. Metropolitan Technological Institute.18(1), p. 61-84, [online] Available at $<$ http://www.ehu.eus/cuadernosdegestion/documentos/150577lj.pdf $>$ [Accessed 17 December 2017].

Gros., C., (2012). The influence of Social Media on consumers during their purchase decision-making process and the implications for marketers. Published thesis (Master degree). Dublin Business School.

Kemp, S., (2018). Digital in 2018: World's internet users pass the 4 billion mark; We Are Social [online]. Available at: https://wearesocial.com/blog/2018/01/global-digital-report-2018 [Accessed 5 Dec. 2018].

Khatib, F., (2016). The impact of social media characteristics on purchase decision: empirical study of Saudi customers in Aseer region. International Journal of Business and Social Science. 7(4), pp.41-50.

Kim, A. and Ko, E. (2012). Do social media marketing activities enhance customer equity? Journal of Business Research.65(10), pp.1480-1486.

Li, W. and Darban, A. (2012). The impact of online social networks on consumers' purchasing decision. Published thesis (Master degree). Jonkoping International Business School.

Medabesh., A. (2015). The impact of electronic advertising on the purchasing of Saudi tourists in Jazan region. Jazan University. 1(1), pp.1-2

Sano., Kaede. (2014). Do Social Media Marketing Activities Enhance Customer Satisfaction, Promote Positive WOM and Affect Behavior Intention? The Association of Commerce Doshisha University. 66(3), pp.491515 , [online] Available at <https://doors.doshisha.ac.jp/duar/repository/ir/16742/017066030404.pdf $>$ [Accessed 17 December 2017].

Scarth, M. (2017). The influence of social media communication on South Africa Millennial consumer purchase intentions of motor vehicle brands. Published thesis (Master degree). University of Pretoria.

Schivinski, B. and Dabrowski, D. (2016). The effect of social media communication on consumer perception of brands. Journal of Marketing Communications. 22(2), pp.1-22

Sema, P. (2013). Does social media affect consumer decision making. United States: Johnson \& Wales University. [online] Available at $<\mathrm{http}: / /$ scholarsarchive.jwu.edu/mba student $/ 24 />$

Toor, A., Husnain, M., and Hussain, T. (2017). The impact of social network marketing on consumer purchase intention in Pakistan. Asian Journal of Business and Accounting. 10(1), pp.167-199, [online] Available at: $<$ https://ajba.um.edu.my/> [ Accessed 19 September 2017]

Zabadi, A., Abdullah, M. and Dammas, A. (2017). Investigate the influence of social networks site on consumer behavior: applying the technology acceptance model. World Wide Journal of Multidisciplinary Research and Development.3(8), pp.38-49.

Zhung, B. (2017). Influence of social media marketing brand loyalty and eWOM towards consumer's purchase intention. Published thesis (Master degree). University Tunku Abdul Rahman 
Appendix

1- Gender

- Male

- Female

2- Age

- Below 20

○ $20-29$

○ $30-39$

○ $40-49$

○ 50 and up

3- How long have you been using the Internet?

- Less than 1 year

○ $1-5$ years

○ 6-10 years

○ 11-15years

- 16 years and above

4- Which of the following social media site do you have an account with?
- Facebook
- Google+
- Instagram
- Twitter
- LinkedIn
- YouTube
- WhatsApp
- Snapchat

5- How often do you use social media?

- All the time

- 4-5 times a week

○ 1-2times a week

- A few times a month

- Never

\section{Instructions:}

a. Please answer ALL the questions on this page.

b. Please mark an answer, which you think best represent your stand byusing the following scale:

1. Strongly disagrees

2. Disagree

3. Neither disagree nor agree

4. Agree

5. Strongly agree

Please consider your recent view of a brand in social media, answers for the following questions.

\begin{tabular}{|c|c|c|c|c|c|}
\hline A- Social Media Marketing Particulars & 1 & 2 & 3 & 4 & 5 \\
\hline \multicolumn{6}{|l|}{$\begin{array}{l}\text { There are many marketing campaigns (advertisements, videos, images, posts, } \\
\text { reviews etc.) by the brand on social media site. }\end{array}$} \\
\hline \multicolumn{6}{|l|}{ The brand regularly updates its contents (posts, pictures, videos, etc.) } \\
\hline \multicolumn{6}{|l|}{ The contents (posts, pictures, videos, reviews, etc.) are relevant to me. } \\
\hline \multicolumn{6}{|l|}{$\begin{array}{l}\text { The contents (posts, pictures, videos, reviews, etc.) are popular among friends or } \\
\text { others. }\end{array}$} \\
\hline \multicolumn{6}{|l|}{$\begin{array}{l}\text { The brand uses applications (mobile apps) and different platform (social media, } \\
\text { website, email, SMS, telephone, etc.) in promoting their products and services. }\end{array}$} \\
\hline \multicolumn{6}{|l|}{ B- Customer Purchase Intention } \\
\hline \multicolumn{6}{|l|}{ The probability that I will buy the product/service is very high. } \\
\hline \multicolumn{6}{|l|}{ I will buy the product/service next time when I need it. } \\
\hline $\begin{array}{l}\text { It is likely that I will continue buying a product/service from the brand in the } \\
\text { future. }\end{array}$ & & & & & \\
\hline
\end{tabular}

